\title{
Climatic variability and human impact during the last 2000 years in western Mesoamerica: evidence of late Classic (AD 600-900) and Little Ice Age drought events
}

\author{
A. Rodríguez-Ramírez ${ }^{1, a}$, M. Caballero ${ }^{2}$, P. Roy ${ }^{3}$, B. Ortega ${ }^{2}$, G. Vázquez-Castro ${ }^{4, b}$, and S. Lozano-García ${ }^{3}$ \\ ${ }^{1}$ Posgrado en Ciencias del Mar y Limnología, Instituto de Geofísica, Universidad Nacional Autónoma de México, \\ Ciudad Universitaria, 04510 Mexico City, Mexico \\ ${ }^{2}$ Instituto de Geofísica, Universidad Nacional Autónoma de México, Ciudad Universitaria, 04510 Mexico City, Mexico \\ ${ }^{3}$ Instituto de Geología, Universidad Nacional Autónoma de México, Ciudad Universitaria, 04510 Mexico City, Mexico \\ ${ }^{4}$ Posgrado en Ciencias de la Tierra, Instituto de Geofísica, Universidad Nacional Autónoma de México, \\ Ciudad Universitaria, 04510 Mexico City, Mexico \\ a now at: Instituto de Ciencias del Mar y Limnología, Universidad Nacional Autónoma de México, Ciudad Universitaria, \\ 04510 Mexico City, Mexico \\ ${ }^{b}$ now at: Escuela Nacional de Estudios Superiores Unidad Morelia, Universidad Nacional Autónoma de México, Ciudad \\ Universitaria, 04510 Mexico City, Mexico
}

Correspondence to: A. Rodríguez-Ramírez (alerdz@unam.mx) and M. Caballero (maga@geofisica.unam.mx)

Received: 27 March 2015 - Published in Clim. Past Discuss.: 20 May 2015

Revised: 4 September 2015 - Accepted: 9 September 2015 - Published: 30 September 2015

\begin{abstract}
We present results of analysis of biological (diatoms and ostracodes) and non-biological ( $\mathrm{Ti}, \mathrm{Ca} / \mathrm{Ti}$, total inorganic carbon, magnetic susceptibility) variables from an $8.8 \mathrm{~m}$ long, high-resolution $\left(\sim 20 \mathrm{yr}_{\text {sample }}{ }^{-1}\right)$ laminated sediment sequence from Lake Santa María del Oro (SMO), western Mexico. This lake lies at a sensitive location between the dry climates of northern Mexico, under the influence of the North Pacific subtropical high-pressure cell and the moister climates of central Mexico, under the influence of the seasonal migration of the intertropical convergence zone and the North American monsoon (NAM). The sequence covers the last 2000 years and provides evidence of two periods of human impact in the catchment, shown by increases in the diatom Achnanthidium minutissimum. The first from AD 100 to 400 (Early Classic) is related to the shaft and chamber tombs cultural tradition in western Mexico, and the second is related to Post-Classic occupation from AD 1100 to 1300. Both periods correspond to relatively wet conditions. Three dry intervals are identified from increased carbonate and the presence of ostracodes and aerophilous Eolimna minima. The first, from AD 500 to 1000 (most intense during the late Classic, from AD 600 to 800), correlates with the end
\end{abstract}

of the shaft and chamber tradition in western Mexico after ca. AD 600. This late Classic dry period is the most important climatic signal in the Mesoamerican region during the last 2000 years, and has been recorded at several sites from Yucatan to the Pacific coast. In the Yucatan area, this dry interval has been related with the demise of the Maya culture at the end of the Classic (AD 850 to 950). The last two dry events (AD 1400 to 1550 and 1690 to 1770) correspond with the onset of, and the late, Little Ice Age, and follow largely the Spörer and Maunder minima in solar radiation. The first of these intervals (AD 1400 to 1550) shows the most intense signal over western Mexico; however this pattern is different at other sites. Dry/wet intervals in the SMO record are related with lower/higher intensity of the NAM over this region, respectively.

\section{Introduction}

Knowledge of past climate and environmental events is critical to understand a wide variety of modern environmental processes and to better estimate causes and effects of future environmental changes. Records from many parts of 
the world have led to the recognition of climate variability in the late Holocene. However, the magnitude, duration and the possible mechanisms of climate change at each location are not clear, especially at tropical latitudes where there are fewer continental records than at higher latitudes (Maasch et al., 2005; Mann et al., 1999).

In Mesoamerica, the last 2000 years appear to have been a time of substantial climatic change with a complex signal, mostly linked to moisture availability (Metcalfe et al., 2000). At present, the influence of the intertropical converge zone (ITCZ) and subtropical high-pressure cells (SHPCs) varies seasonally, showing latitudinal shifts associated with the tropospheric equator-pole temperature gradient in each hemisphere, and the thermal contrast between the hemispheres (Haug et al., 2001; Nyberg et al., 2002). The seasonal shift in insolation and latitudinal location of the ITCZ and SHPCs brings shifts in moisture availability that affect most of Mesoamerica, with an intense summer rainfall season associated with the northerly location of the ITCZ and the onset of the North American monsoon (NAM). Past changes in the amplitude, intensity and location of the ITCZ and SHPCs and in the intensity of the NAM are therefore likely explanations for the changes documented in the Mesoamerican geological records (Hodell et al., 2005a; Metcalfe et al., 2010; Haug et al., 2003; Barron et al., 2012). Long-term changes in these climatic systems can be recorded in the sediment archives of lakes in the region, given that lakes are sensitive to climatic variations, which can lead to changes in their stratification patterns, their water chemistry and/or their biological associations. Western Mexico's precipitation is modulated by the position of the ITCZ and the intensity of the NAM, however, most of the available palaeo-limnological records for Mesoamerica are concentrated in the highlands of central Mexico or in the Yucatan region (Metcalfe et al., 2000).

In this paper we present a multi-proxy, high-resolution $(\sim 20 \mathrm{yr}$ per sample) study of a laminated sediment sequence from a closed lake basin in western Mexico, Santa María del Oro, Nayarit (Fig. 1), and infer past climatic events that have affected western Mesoamerica during the past 2000 years. This lake currently sits at the intersection between the arid climates of northern Mexico, mostly under the influence of the North Pacific SHPC, and the temperate, sub-humid to humid climates of central Mexico (García-Oliva et al., 2002), under the influence of the ITCZ and the NAM systems. This record gives clear evidence of two intense drought periods, the late Classic (AD 600 to 800) and the onset of the Little Ice Age (AD 1400 to 1550), and a third, less intense dry phase around AD 1690 to 1770.

\section{Site description}

Santa Maria del Oro (SMO, $21^{\circ} 23^{\prime} \mathrm{N}, 104^{\circ} 35^{\prime} \mathrm{W}$; $750 \mathrm{~m}$ a.s.1.) is a topographically closed freshwater crater lake at the western end of the Trans-Mexican Volcanic Belt

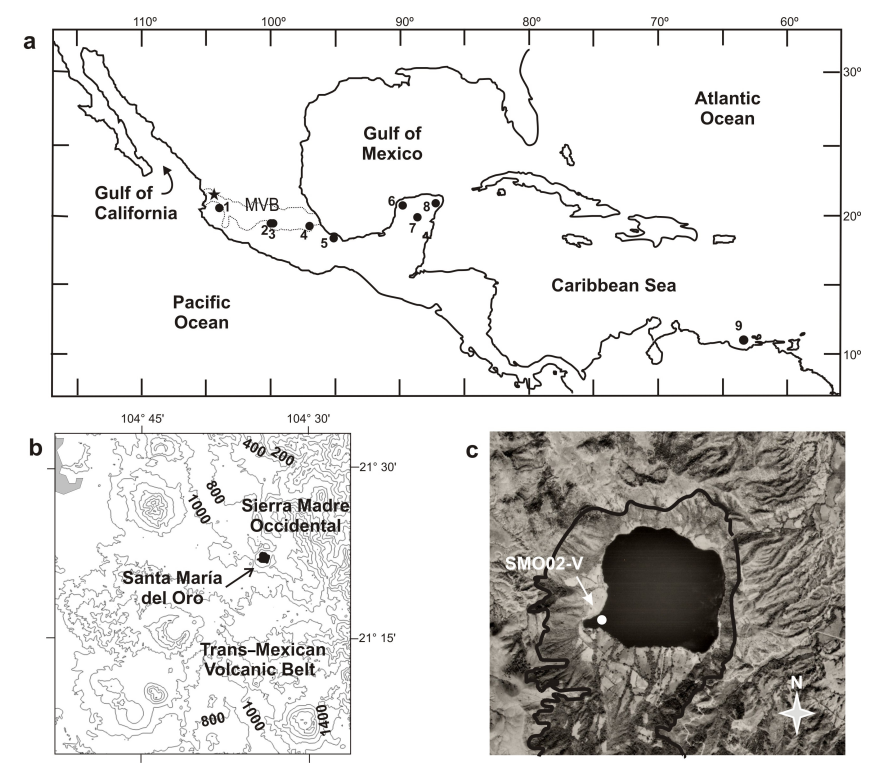

Figure 1. Location maps (a) map of Mexico showing the research site (star) and locations discussed in the text from west to east: 1 . Juanacatlán (Metcalfe et al., 2010), 2. La Luna (Cuna et al., 2014), 3. Chignahuapan (Caballero et al., 2002), 4. Aljojuca (Bhattacharya et al., 2015), 5. Lago Verde (Lozano-García et al., 2007; LozanoGarcia et al., 2005), 6. Aguada X'caamal (Hodell et al., 2005b), 7. Lake Chichancanab (Hodell et al., 2001, 2005a), 8. Punta Laguna (Curtis et al., 1996) and 9. Cariaco Basin (Haug et al., 2001, 2003). The dotted line delimits the Trans-Mexican Volcanic Belt (MVB). (b) Map of the research area with the location of Lake Santa María del Oro, Nayarit, Mexico. (c) Aerial photograph showing the catchment (continuous black line) of Lake Santa María del Oro and the location of the SMO02-V core site.

and lies only $65 \mathrm{~km}$ from the Pacific coast (Fig. 1). Catchment rocks are dominated by dacite-rhyolite and basaltic andesite. Minor exposures of basaltic lava flows are present on the northern wall of the crater. There are no carbonate rock outcrops in the catchment or in the surrounding areas (Ferrari et al., 2003; Vázquez-Castro et al., 2008).

The climate at SMO is warm and sub-humid, with monthly average temperatures that range from 16.5 to $25^{\circ} \mathrm{C}$ (Station 18005-Cerro Blanco - Servicio Meteorológico Nacional). This region receives average annual precipitation of $\sim 1200 \mathrm{~mm}$, mainly during the warm summer months (June to September) when the ITCZ is at its most northerly location and the NAM is active (Liebmann et al., 2008; Berbery, 2001). During summer, tropical storms and hurricanes can also bring moisture from the Pacific (Castro, 2010; GarcíaOliva et al., 2002). The rest of the year (October to May) is relatively dry, particularly during spring.

SMO is a nearly round, $\sim 2 \mathrm{~km}$ diameter lake. It has a maximum depth of $65.5 \mathrm{~m}$ and a mean depth of $46 \mathrm{~m}$ (Serrano et al., 2002). The crater has steep slopes but there is a small flat and shallow bay (12 $\mathrm{m}$ deep) where the core for this study was retrieved (Fig. 1). The lake receives inflows 
Table 1. Radiocarbon (AMS) dates of core SMO02-V, Lake Santa Maria del Oro, Nayarit (Vázquez-Castro et al., 2008). Calendar years were calculated using the program Calib 5.0 (Stuiver et al., 2005) with the IntCal04 data set (Reimer et al., 2004).

\begin{tabular}{|c|c|c|c|c|}
\hline Laboratory ID & $\begin{array}{l}\text { Depth } \\
(\mathrm{cm})\end{array}$ & $\begin{array}{l}\text { Material } \\
\text { dated }\end{array}$ & $\begin{array}{l}\text { Radiocarbon } \\
\text { age (year BP) }\end{array}$ & $\begin{array}{l}2 \sigma \text { range } \\
\text { (cal. year) }\end{array}$ \\
\hline Beta -186780 & 125.0 & peat & $400 \pm 40$ & AD $1432-1526$ \\
\hline Beta -176359 & 246.5 & peat & $660 \pm 40$ & AD 1341-1397 \\
\hline Beta -186781 & 278.0 & peat & $700 \pm 40$ & AD 1256-1327 \\
\hline Beta -176360 & 366.5 & wood & $850 \pm 40$ & AD $1154-1275$ \\
\hline Beta -176361 & 404.7 & peat & $990 \pm 40$ & AD 983-1073 \\
\hline Beta -176362 & 791.8 & peat & $2250 \pm 40$ & $324-202$ BC \\
\hline Beta -169050 & 837.0 & wood & $2340 \pm 40$ & $520-357 \mathrm{BC}$ \\
\hline
\end{tabular}

directly from precipitation, seasonal run-off and groundwater, and loses water to evaporation and seepage. The lowest point of the crater is on the north-eastern side, where the natural sill has been anthropogenically modified. Today it lies $\sim 5 \mathrm{~m}$ above the lake level (755 $\mathrm{m}$ a.s.1.). The closed nature of the basin and its relatively unpolluted condition make this lake an ideal palaeo-environmental research site, where lake chemistry depends mostly on the precipitation-evaporation balance. At present $\mathrm{SMO}$ is a freshwater, $\left[\mathrm{HCO}_{3}^{-}\right]-\left[\mathrm{Cl}^{-}\right]$, $\left[\mathrm{Na}^{+}\right]>\left[\mathrm{Mg}^{2+}\right] \gg\left[\mathrm{Ca}^{2+}\right]$, oligotrophic, warm monomictic lake, with a winter mixing period (Caballero et al., 2013); the oxycline lies between 13 and $20 \mathrm{~m}$ depth the rest of the year. Currently the lake ostracode fauna is dominated by Potamocypris variegata Brady and Norman, Cypridopsis vidua Müller and Darwinula stevensoni Brady and Robertson and the planktonic diatom flora by Aulacoseira granulta (Ehrenberg) Simonsen, in association with Nitzschia amphibia Grunow.

\section{Methods}

Four cores between 4 and $9 \mathrm{~m}$ length were recovered from the shallow south-western bay (12 m depth) of SMO in 2002 (Fig. 1c) with a Usinger coring system (Mingram et al., 2007). All cores were split, described, photographed and sampled at the Instituto de Geofísica, Universidad Nacional Autónoma de México (UNAM) and, unless otherwise specified, all analyses were performed there. The longest core (SMO02-V, $8.8 \mathrm{~m}$ ) was sampled, on average, at $5 \mathrm{~cm}$ intervals for magnetic susceptibility (MS), biological (ostracodes, diatoms, pollen) and geochemical analyses (total inorganic carbon, total organic carbon, X-Ray fluorescence elemental analysis). Seven samples for ${ }^{14} \mathrm{C}$ AMS radiocarbon age determinations were collected at selected levels, dried and sent without further treatment to a commercial dating laboratory (Beta Analytic). The seven dates (Table 1) were calibrated to calendar years with Calib 5.0 (Stuiver et al., 2005) and the IntCal04 data set (Reimer et al., 2004). The age model (Fig. 2) assumed constant, linear sediment accumulation rates between the dates and anchored the top sediment

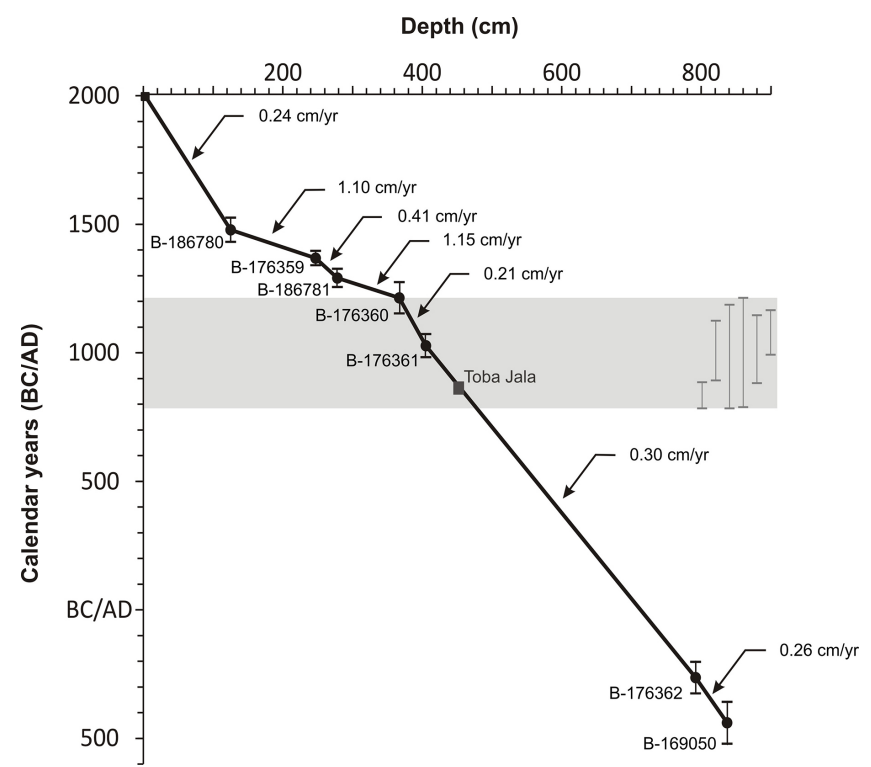

Figure 2. Age model of core SMO02-V, Lake Santa Maria del Oro, Nayarit. Details of dates are listed in Table 1. Sedimentation rates are indicated above the line. The stratigraphic position of Toba Jala in the SMO02-V sequences is shown with the black square; grey bars and the grey shaded area represent the range of calibrated ages reported for this volcanic event (Sieron and Siebe, 2008).

to the year of coring (2002) (Vázquez-Castro et al., 2008). The sediment stratigraphy, age model, MS and total inorganic carbon (TIC) data were published in Vázquez-Castro et al. (2008). Here we present MS data, expressed in dimensionless international SI units, and TIC expressed as $\mathrm{CaCO}_{3} \%$, together with new diatom, ostracode, $\mathrm{Ca}$ and $\mathrm{Ti}$ data from the SMO02-V core.

\subsection{X-Ray Fluorescence}

Thirty nine freeze-dried sediment samples were chosen, on average every $20 \mathrm{~cm}$, for X-Ray fluorescence (XRF) elemental analysis. Samples were homogenized and ground to 200 mesh using an agate mortar. Elemental concentrations were measured at the Institute of Geology, UNAM, using a Siemens SRS 3000 wavelength dispersive XRF spectrometer with a precision of $5 \%$. Titanium and calcium concentrations are expressed as percentages; $\mathrm{Ca}$ was normalized against titanium and expressed as a $\mathrm{Ca} / \mathrm{Ti}$ mass ratio.

\subsection{Diatoms}

For diatom analysis, 108 samples were chosen, on average at $10 \mathrm{~cm}$ intervals, of which 78 contained diatoms. Dry sediment $(0.5 \mathrm{~g})$ was cleaned successively with $\mathrm{HCl}(10 \%)$, $\mathrm{H}_{2} \mathrm{O}_{2}$ and $\mathrm{HNO}_{3}$. Permanent slides were made with $200 \mu \mathrm{L}$ of clean sediment material and embedded with Naphrax ${ }^{\circledR}$ mounting medium. Minimum counts of 300 valves were undertaken in most samples, but 22 had low diatom abundance 
and only 100 valves were counted. Diatom counts were done with an Olympus BX50 microscope with interferential phase contrast at 1000x magnification. Species composition is reported as relative abundance (\%), and total abundance is reported as valves per gram of dry sediment $\left(\mathrm{vgds}^{-1}\right)$.

\subsection{Ostracodes}

For ostracodes, the same 108 samples were analysed, but only 57 levels contained the remains of ostracodes. Two cubic centimetres from each sample were freeze-dried, from which $1 \mathrm{~g}$ of dry sediment was disaggregated by standard methods (Delorme, 1990; Forester, 1988) and wet-sieved $(63 \mu \mathrm{m})$. Ostracode valves were picked under an Olympus SZX12 stereo microscope, counted, determined to species taxonomic level and stored on micropalaeontological slides. Care was taken to pick whole adult valves to allow species identification, and juvenile valves were counted separately. Ostracode counts are expressed as valves per gram of dry sediment $\left(\mathrm{vgds}^{-1}\right)$.

\section{Results}

\subsection{Core description}

Sedimentation rates varied between 0.21 and $1.15 \mathrm{~cm} \mathrm{yr}^{-1}$ (Fig. 2) and, according to the age model (Fig. 2), the base of the core $(882 \mathrm{~cm})$ is ca. 2600 years old. Average sample resolution was about 23 years per sample. The SMO02$\mathrm{V}$ sequence consists of sand/silt laminations with intercalated woody peat layers. Individual silt layers can be of $\sim 1-$ $3 \mathrm{~mm}$ up to $60 \mathrm{~mm}$ in thickness and either light-brown calcareous, greenish, reddish or dark brown (Vázquez-Castro et al., 2008). A $13 \mathrm{~mm}$ thick grey tephra layer at $454 \mathrm{~cm}$ depth was identified as the Toba Jala from the nearby Ceboruco volcano; according to our chronology, this tephra dates to $\mathrm{AD} \sim 860$ (Vázquez-Castro et al., 2008), a date that falls within the range of calibrated radiometric ages reported for this tephra (Fig. 2) (Sieron and Siebe, 2008). The light-brown calcareous silt layers contain either authigenic carbonates or ostracodes, and are more frequent towards the top of the core, whereas woody peat layers are more frequent towards the bottom. There is no evidence for hiatuses, erosion features or slumping structures in the cores.

\subsection{Non biological variables}

Magnetic susceptibility (MS) (Fig. 3) fluctuates along the core between 24 and $520 \times 10^{-6}$ SI, with lowest values $\left(<200 \times 10^{-6} \mathrm{SI}\right)$ observed between 530 and $490 \mathrm{~cm}$, and between 200 and $150 \mathrm{~cm}$. The highest MS values $\left(>300 \times 10^{-6} \mathrm{SI}\right)$ are mainly present from 600 to $530 \mathrm{~cm}$ and from 490 to $420 \mathrm{~cm}$. Titanium contents range between 0.3 and $1.5 \%$ with values lower than average $(<0.8 \%)$, concentrated between 530 and $370 \mathrm{~cm}$ and 200 and $150 \mathrm{~cm}$. The highest values $(>1.3 \%)$ in the record are present between 450 and $420 \mathrm{~cm}$.

TIC as its $\mathrm{CaCO}_{3}$ equivalent varies along the core from 0 to $59 \%$ (Fig. 3), in a pattern nearly opposite to magnetic susceptibility, showing in general higher values $(>20 \%)$ between 530 and $370 \mathrm{~cm}, 320$ and $240 \mathrm{~cm}, 200$ and $150 \mathrm{~cm}$ and 120 and $100 \mathrm{~cm}$. The $\mathrm{Ca} / \mathrm{Ti}$ weight ratio ranges between 1.4 and 175 and shows above average values $(>15)$ between 530 and $370 \mathrm{~cm}$ and at $200 \mathrm{~cm}$.

\subsection{Diatoms}

Diatom abundance shows several intervals of values that are lower than average $\left(<40 \times 10^{6} \mathrm{vgds}^{-1}\right.$, Fig. 4$)$, but the lowest abundances are recorded between 740 and $690 \mathrm{~cm}$ and from 380 to $330 \mathrm{~cm}$. Sixty-four species are recorded in the sequence, nine with relative abundances $>20 \%$ in more than one sample (Fig. 3). Aulacoseira granulata, Nitzschia amphibia and small species of Fragilaria sensu lato (Staurosira construens, Staurosirella pinnata, Pseudostaurosira parasitica, $P$. brevistriata) are the dominant species in the record. Achnanthidium minutissimum (Kützing) Czarnecki has a preferential distribution between 750 and $650 \mathrm{~cm}$ and from 400 to $250 \mathrm{~cm}$, Amphora libyca Ehrenberg and Hippodonta luneburgensis (Grunow) Lange-Bertalot, Metzeltin and Witkowski have higher abundances in the top $500 \mathrm{~cm}$ of the core and Eolimna minima (Grunow) Lange-Bertalot and W. Schiller shows a distinctive distribution with maxima between 530 and $420 \mathrm{~cm}$ and two less important peaks between 200 and $110 \mathrm{~cm}$ and from 75 to $60 \mathrm{~cm}$.

\subsection{Ostracodes}

Ostracode total abundance shows two distinct intervals with high values ( $>1000$ adult $\mathrm{vgds}^{-1}$ ), the first between 530 and $420 \mathrm{~cm}$ and the second between 200 and $110 \mathrm{~cm}$. A smaller peak at 75 to $60 \mathrm{~cm}$ is also present, while the rest of the core has very low $\left(<100\right.$ adult $\left.\mathrm{gds}^{-1}\right)$ ostracode concentration (Fig. 3). Six species are recorded in the sequence; Candona patzcuaro Tressler is the most abundant and constant along the core in association with Potamocypris variegata and minor numbers of Chlamydotheca arcuata Sars. Cypridopsis vidua and Darwinula stevensoni are also present along the core, but show a preferential distribution between the 530 and $420 \mathrm{~cm}$ interval. Limnocythere verrucosa Hoff is only present as juvenile valves, and shows maximum concentrations between 570 and $530 \mathrm{~cm}$.

\section{Interpretation of sediment variables}

MS indicates the abundance of magnetic minerals that reach a lake, mainly by surface run-off from the catchment area or, on occasion, from volcanic activity (Evans and Heller, 2003). Titanium is an element that originates from minerals in the catchment rocks and its abundance in lacustrine 

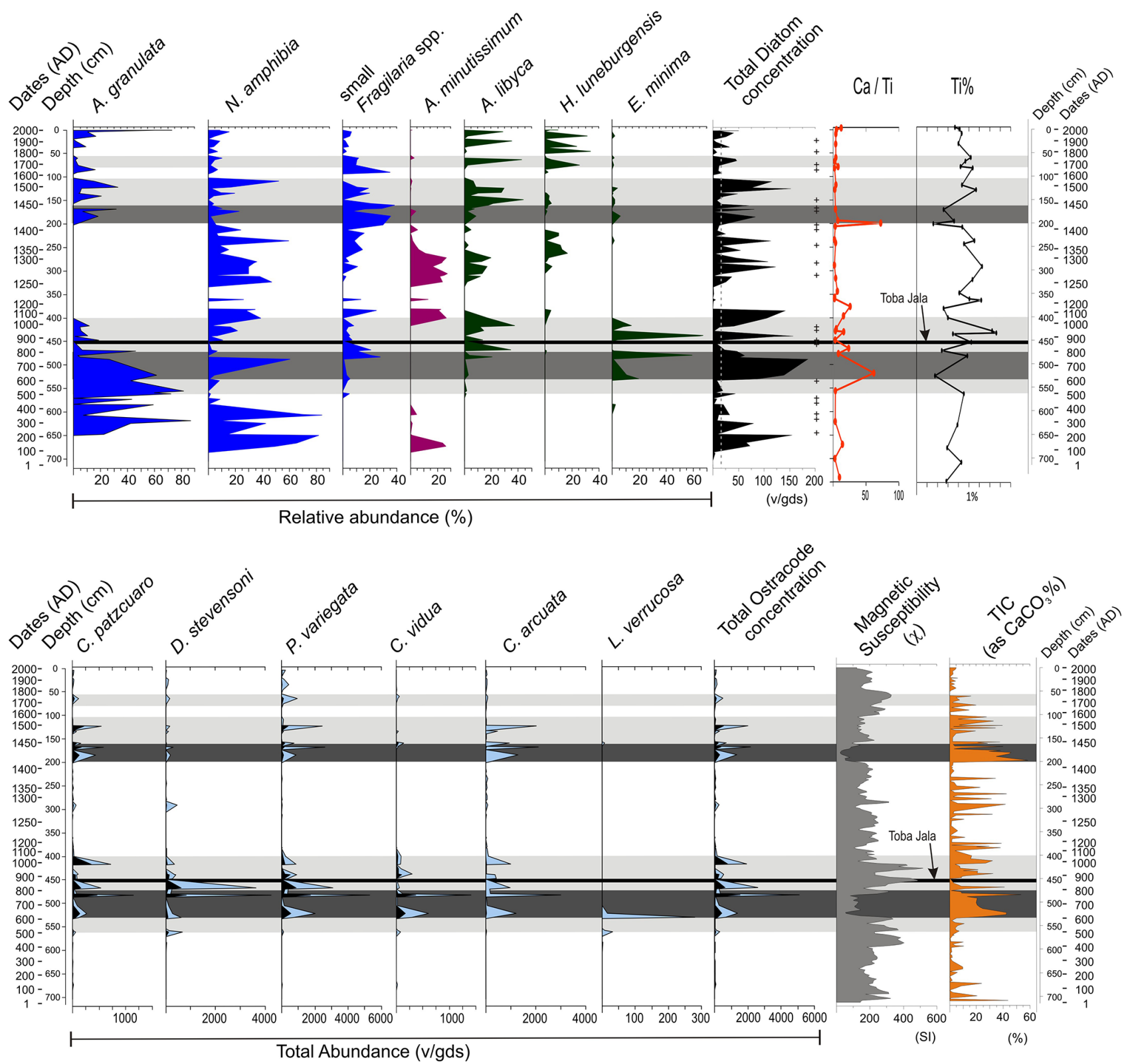

Figure 3. Biological (diatoms and ostracodes) and non-biological (Ca / Ti, Ti, magnetic susceptibility and TIC) variables from core SMO02V, Santa María del Oro, Nayarit, Mexico. TIC represents total inorganic carbon. Small Fragilaria spp. includes: Staurosira construens, Staurosirella pinnata, Pseudostaurosira parasitica, P. brevistriata, of which only P. brevistriata had $<20 \%$ abundance in the sequence. Grey shaded areas highlight periods with high Eolimna minima and ostracode valves abundance; dark grey areas highlight periods when high Eolimna minima and ostracode valves abundance correspond with low magnetic susceptibility and high TIC. The black line represents the Toba Jala. Samples with low diatom counts are marked with a cross (+).

sediments is also indicative of surface run-off to the lake and erosion (Metcalfe et al., 2010; Sosa-Nájera et al., 2010). Both variables can therefore be used to identify times of higher or lower precipitation and surface transport of sediments to the lake.

On the other hand, given that there are no carbonate rocks in the lake catchment, high values of TIC are indicative of times of higher authigenic carbonate precipitation. This is a process that currently occurs in SMO during the warmer part of the year (Caballero et al., 2013) and that is, in general, favoured by high evaporation rates, leading to increased electric conductivity, alkalinity and $\mathrm{pH}$ (Eugster and Hardie, 1978; Gierlowski-Kordesch, 2010). Calcium may originate from the minerals in the catchment but it is also incorporated in authigenic carbonates. Sosa-Nájera et al. (2010) demonstrated that in this lake, higher $\mathrm{Ca}$ concentrations have corre- 


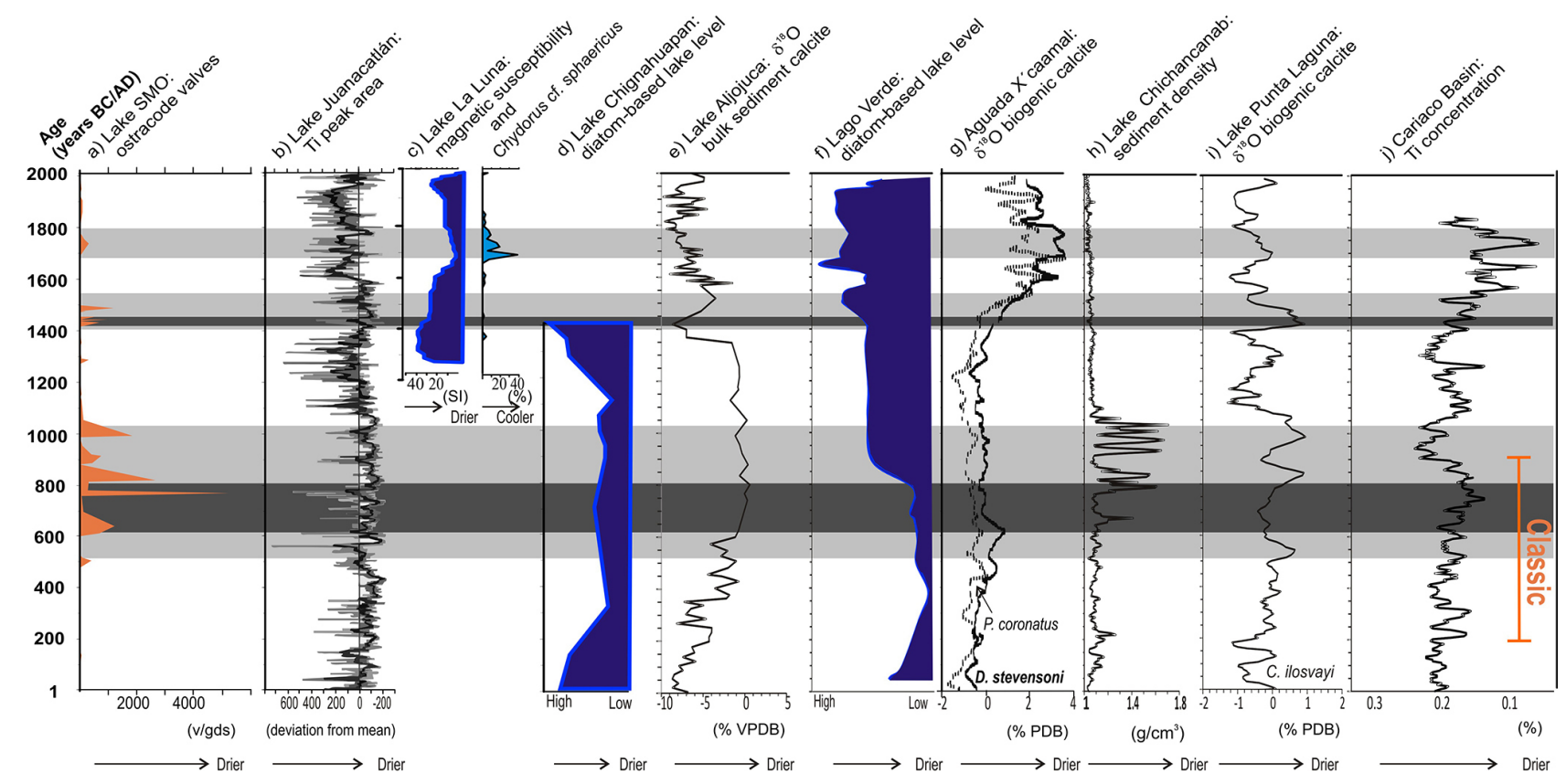

Figure 4. Correlation between selected palaeo-environmental records for the last 2000 years in Central Mexico and circum-Caribbean (location of sites shown in Fig. 1): (a) ostracode valve concentrations from Lake Santa María del Oro (SMO; this study); (b) titanium record from Lake Juanacatlán (Metcalfe et al., 2010); (c) magnetic susceptibility and Chydourus cf. sphaericus abundance from Lake La Luna (Cuna et al., 2014); (d) diatom-based lake level fluctuations from Lake Chignahuapan (Caballero et al., 2002); (e) bulk sediment calcite $\delta^{18} \mathrm{O}$ from Lake Aljojuca (Bhattacharya et al., 2015); (f) diatom-based lake level fluctuations from Lago Verde (Lozano-García et al., 2010); (g) biogenic calcite $\delta^{18} \mathrm{O}$ from Aguada X'caamal (Hodell et al., 2005b); (h) sediment density from Lake Chichancanab (Hodell et al., 2005a); (i) biogenic calcite $\delta^{18} \mathrm{O}$ from Punta Laguna (Curtis et al., 1996). (j) titanium record from marine Cariaco Basin (Haug et al., 2001). VPDB represents Vienna Pee Dee Belemnite standard, PBD represents Pee Dee Belemnite standard. Shaded areas correspond to the time intervals of shaded areas in Fig. 3.

lated with historical droughts during the last 700 years, supporting the interpretation that in SMO, high calcium values are mostly related with carbonate deposition during times of higher evaporation. Nevertheless, Ca was normalized against Ti to reduce the detrital signal in this element. High TIC and high $\mathrm{Ca} / \mathrm{Ti}$ values in this record can, therefore, be taken as indicators of increased carbonate deposition during times of lower precipitation and higher evaporation rates, leading to relatively high lake water electric conductivity, $\mathrm{pH}$ and alkalinity. Given the contrasting environmental conditions that lead to high MS and Ti versus high TIC and $\mathrm{Ca}$, it is not surprising that they show nearly opposite patterns of downcore variations. Together, these records enable identification of two intervals of intense evaporation and reduced surface run-off to the lake, the first from 530 to $490 \mathrm{~cm}$ (AD 600 to 800 ) and the second from 200 to $150 \mathrm{~cm}$ (AD 1400 to 1450).

With respect to the biological variables, three ecological groups can be identified in the diatom record. (1) A planktonic/tychoplanktonic association is identified, dominated by Aulacoseira granulata, Nitzschia amphibia and small Fragilaria spp., which is abundant along most of the sequence (Fig. 3); this association includes the two main diatom species present in the modern lake plankton (Caballero et al., 2013). (2) A benthic/periphytic association is identified in which Amphora libyca, Hippodonta luneburgensis and Eolimna minima, are the main species. These periphytic genera (Amphora) and species (H. luneburgensis, E. minima) are currently distributed in the shallower environments of the lake (Caballero et al., 2013); E. minima in particular is an aerophilic species (Wolfe and Härtling, 1996; Van Dam et al., 1994). Its distinctive distribution along the record (shaded areas in Fig. 3) suggests intervals of particularly shallow lake levels. (3) An eutrophication/human impact association is defined by the presence of Achnanthidium minutissimum, a species that has been considered by some authors as a colonizer in disturbed environments (Peterson and Stevenson, 1992; Hodgson et al., 1997). In Mexico, this species has been recorded in the plankton of tropical lakes in areas that have been severely altered by human activities (Caballero et al., 2006; Vázquez and Caballero, 2013). This interpretation is further supported by the presence of Zea mays pollen grains in the same segments of the core (S. Sosa-Nájera, personal communication, 2013). The ostracode record can be interpreted based on the study of this lake by Caballero et al. (2013), who found that ostracodes were most abundant in shallow water environments with littoral vegetation and 
a low sediment supply. Given that the dominant species in the SMO record are the same as those that currently live in this lake ( $P$. variegata, D. stevensoni, $C$. vidua) high ostracode abundances are taken to be indicative of these conditions, which are consistent with lower surface run-off. The ostracode relative abundance record and the distribution of E. minima suggest three zones of lake levels that are lower than average (Fig. 3): 560 to $410 \mathrm{~cm}$ (AD 500 to 1000), 200 to $100 \mathrm{~cm}$ (AD 1400 to 1550 ) and 75 to $56 \mathrm{~cm}$ (AD 1690 to 1770). The first two periods include the two events of intense evaporation identified in the geochemical record.

\section{Palaeo-environmental history of Lake SMO}

The MS, Ti, Ca / Ti, ostracode and diatom records together (Fig. 3) enable reconstruction of the environmental history of Lake SMO during the last 2000 years. Low values of $\mathrm{Ca} / \mathrm{Ti}$, TIC and ostracode abundance, together with the absence of benthic/periphytic diatoms in the record prior to AD 500 indicate that Lake SMO was generally deeper and the lake water was more dilute from $100 \mathrm{BC}$ to AD 500. An early phase of human impact is identified by the abundance of $A$. minutissim from $100 \mathrm{BC}$ to $\mathrm{AD} 300$, possibly related with the local expression of the shaft and chamber tomb tradition (200 $\mathrm{BC}$ to AD 600) characteristic of western Mexico (Beekman, 2010; Barrera-Rodríguez, 2006).

After AD 500 the lake experienced a low-level stage defined mainly by an increase in E. minima and ostracode concentrations, by low MS and also by its magnetic mineralogy (Vázquez-Castro et al., 2008). This period of low lake level extended from AD 500 to 1000 , with the interval from AD 600 to 800 representing the driest conditions (lowest MS and $\mathrm{Ti}$ values and highest $\mathrm{TIC}$ and $\mathrm{Ca} / \mathrm{Ti}$ ratios). This first low lake level phase in SMO correlates with what is known as the late Classic (AD 600 to 900) period in the development of Mesoamerican cultures, characterized by a decline of the Teotihuacan culture in central Mexico after AD 650 (Manzanilla, 2011) and development of Maya cities in the Yucatan region, which ended abruptly between AD 850 and 950. In western Mexico in general and specifically in the state of Nayarit (Barrera-Rodríguez, 2006), this was a time of cultural transition as the shaft and chamber tomb tradition ended by AD 600 (Barrera-Rodríguez, 2006). In the SMO record there is no evidence of human impact during this dry interval. Thus, the inferred dry conditions in this period reflect a true climatic signal, not obscured by anthropogenic activities.

This late Classic drought has been identified in several records from Mexico, particularly from Yucatan (Hodell et al., 2005a; Metcalfe et al., 2010; Caballero et al., 2002; Lozano-García et al., 2010; Curtis et al., 1996; Bhattacharya et al., 2015) (Fig. 1), to the extent that it is referred to as the "Great Maya Drought" (Gill, 2001) and has been put forward as an important factor in the collapse of the Maya culture at the end of the Classic (AD 850 to 950). The exact timing of these droughts varies across sites but in general, it is centred in a similar time interval as in SMO (AD 500 to 1000) (Fig. 4). In some records, the droughts show a recurrent or cyclic pattern (Haug et al., 2003; Hodell et al., 2001; Curtis et al., 1996) which could explain the fluctuating values of the geochemical records of Lake SMO (alternating high and low TIC, Ti and MS) from AD 800 to 1000 and even until AD 1200.

After AD 1000 low abundances of E. minima and ostracode valves suggest that the lake level in SMO recovered. However TIC, $\mathrm{Ca} / \mathrm{Ti}$ and $\mathrm{Ti}$ still fluctuated between high and low values until $A D \sim 1200$. After this date, the age model (Fig. 2) also suggests that sedimentation rates increased (from $\leq 0.3$ to $>1 \mathrm{~cm} \mathrm{yr}^{-1}$ ), which is in accordance with higher surface run-off to the lake. Moister conditions after AD 1000 and especially from AD 1200 to 1400 correlate with moist conditions inferred from the Ti record from Lake Juanacatlán, a site also in western Mexico (Metcalfe et al., 2010). Between AD 1000 and 1400, however, the presence of A. minutissimum points to a time of human disturbance in the system. This trend in human occupation at Lake SMO agrees with recent archaeological findings in Nayarit that show late Post-Classic (AD 1100 to 1400) occupations (Gálvez-Rosales, 2006) and is also in agreement with the late Post-Classic cultural peak reached in western Mesoamerica by groups like the Purepecha or Tarascans (Pollard, 2005).

From AD 1400 to 1550 the increase in TIC, E. minima and ostracode abundance, the decline in MS as well as the magnetic mineralogy (Vázquez-Castro et al., 2008) suggest that the lake level in SMO dropped again. The lowest MS and Ti values and highest TIC suggest that the reduction in moisture was most intense from AD 1400 to 1450 . This second dry interval in the Lake SMO record corresponds with the onset of the Little Ice Age. This period has also been recorded as a time of reduced moisture and lower lake levels in other Mesoamerican records (Metcalfe et al., 2010; Hodell et al., 2005b; Cuna et al., 2014) (Fig. 4) and represents the climatic scenario for the Spanish conquest of Mesoamerica in 1521.

Water levels recovered in SMO between AD 1550 and 1690 , but a third, less intense period of reduced moisture availability is evident in the records, with a slight increase in E. minima and ostracode concentrations between AD 1690 and 1770. This smaller reduction in moisture is coeval with the end of the Little Ice Age and shows the two periods of cooling in the Little Ice Age, also evident in the record from Lago Verde, eastern Mexico (Lozano-García et al., 2007).

\section{Palaeo-climate implications}

The data from Lake SMO enabled us to identify two periods of human impact that are consistent with findings from recent archaeological research in the area (Barrera-Rodríguez, 2006; Gálvez-Rosales, 2006), the first related with the shaft 
and chamber tomb tradition (100 BC to AD 300) and the second during the late Post-Classic (AD 1100 to 1400). It is interesting to note that these periods of occupation correspond with times of moister conditions, while there is no evidence of human impact in this lake during the drier late Classic (AD 600 to 900$)$.

The biological and non-biological variables in the sediment of Lake SMO provide solid evidence of three intervals that are drier than average, the most intense from AD 600 to 800 , correlating mostly with the late Classic, and the other two related with the onset (AD 1400 to 1550) and the late (AD 1690 to 1770) Little Ice Age. There is also evidence of a wetter late Post-Classic period (AD 1200 to 1400). In this region where climate is controlled by the seasonal shift of the North Pacific SHPC, the ITCZ and the onset of the NAM, conditions that are drier than average can be related to an expansion of the North Pacific SHPC, a southward migration of the ITCZ and a less active NAM (Haug et al., 2003; Metcalfe et al., 2010). Other mechanisms that could bring wetter/drier conditions in this region are changes in the frequency or strength of "La Niña"/"El Niño", as today "La Niña" is related with summers that are wetter than average (Magaña et al., 2003; Metcalfe et al., 2010). Changes in the paths or frequency of Pacific tropical storms and hurricanes could also be elements that control the moisture balance in this area.

The data presented in this paper provide further evidence that the late Classic drought (AD 500 to 1000) was the most important one in Mesoamerica during the last 2000 years, affecting the whole region from Yucatan to the Pacific coast (Fig. 4); it was not only a circum-Caribbean feature. In SMO the most intense phase is recorded from AD 600 to 800. The variable nature of the Lake SMO record from AD 800 to 1200 seems consistent with the proposed recurrent nature of droughts, which has been suggested to follow cycles in solar activity (mainly 50 and 200 years), (Hodell et al., 2001, 2005a; Haug et al., 2003). This period of strong fluctuations in the Lake SMO record also correlates with the onset of conditions that are warmer than average over the northern hemisphere from AD 830 to 1100 during the Medieval Climatic Anomaly (PAGES-2k-Consortium, 2013) that locally correlated with warmer sea surface temperatures in the Gulf of California (Barron et al., 2002).

The dry interval from AD 1400 to 1550 which corresponds with the onset of the Little Ice Age, correlates closely with the Spörer minimum in solar activity. The less intense dry period near the end of the Little Ice Age (AD 1690 to 1770) correlates partly with the Maunder solar minimum. A two-phase Little Ice Age cooling, partly following the two solar minima, is also present in the record from Lago Verde, eastern Mexico (Lozano-García et al., 2007). In lakes SMO and Juanacatlán (both in western Mexico, Fig. 1) the Spörer minimum shows the most intense signal. However, in other records in central and eastern Mexico, the Maunder minimum represents the driest and/or coldest period (Haug et al., 2003; Cuna et al.,
2014) (Fig. 4). Furthermore, in some records, the two periods seem to merge into a single, longer Little Ice Age drought (Hodell et al., 2005b). These Little Ice Age droughts seem to be related with the Spörer and Maunder solar minima.

The good coherence of the biological and non-biological proxies, the solid chronology and the high-resolution nature of the Lake SMO record yield insights into the environmental and climatic processes that have affected this lake during the last 2000 years, and provide insight into the interplay between climatic and anthropogenic influences on this lake.

Acknowledgements. This research was possible thanks to economical support from projects UNAM-DGAPA IN107928, UNAM-DGAPA IN203102 and CONACyT G28528T. The authors are thankful for the technical support from: Susana Sosa Nájera, Antonio González, Teodoro Hernández, Luis Oseguera, Rufino Lozano and Teresa Pi. Total inorganic carbon determinations were performed in the facilities of the Limnological Research Center, University of Minnesota. A. Rodríguez wishes to thank Richard Forester ${ }^{\dagger}$ for his help in ostracode taxonomy, support from the Postgraduate Program in Marine Sciences and Limnology of the Universidad Nacional Autónoma de México (UNAM) and the economic support from CONACyT for his $\mathrm{PhD}$ research.

Edited by: M. Grosjean

\section{References}

Barrera-Rodríguez, R.: El proyecto arqueológico El Cajón, Nayarit, in: Entre ríos y montañas sagradas: arqueología en El Cajón, Nayarit, edited by: Barrera-Rodríguez, R., Consejo Nacional para la Cultura y las Artes, Instituto Nacional de Antropología e Historia, Comisión Federal de Electricidad., México, 13-28, 2006.

Barron, J. A., Bukry, D., and Bischoff, J. L.: A 2000-yr-long record of climate from the Gulf of California, Proceedings of the Nineteenth Pacific Climate Workshop, Asilomar, Pacific Grove, CA, 11-21, 2002.

Barron, J. A., Metcalfe, S. E., and Addison, J. A.: Response of the North American monsoon to regional changes in ocean surface temperature, Paleoceanography, 27, PA3206, 3201-3217, 2012.

Beekman, C. S.: Recent research in western Mexican archaeology, J. Archaeol. Res., 18, 41-109, 2010.

Berbery, E. H.: Mesoscale moisture analysis of the North American monsoon, J. Climate, 14, 121-137, 2001.

Bhattacharya, T., Byrne, R., Böhnel, H., Wogau, K., Kienel, U., Ingram, L., and Zimmerman, S.: Cultural implications of late Holocene climate change in the Cuenca Oriental, Mexico, Proc. Natl. Acad. Sci., 112, 1693-1698, 2015.

Caballero, M., Ortega, B., Valadez, F., Metcalfe, S., Macias, J. L., and Sugiura, Y.: Sta. Cruz Atizapan: a 22-ka lake level record and climatic implications for the late Holocene human occupation in the Upper Lerma Basin, Central Mexico, Palaeogeogr. Palaeoclimatol. Palaeoecol., 186, 217-235, 2002.

Caballero, M., Vázquez, G., Lozano-García, S., Rodríguez, A., Sosa-Nájera, S., Ruiz-Fernández, A. C., and Ortega, B.: Present Limnological Conditions and Recent (ca. 340 yr) Palaeolimnol- 
ogy of a Tropical Lake in the Sierra de Los Tuxtlas, Eastern Mexico, J. Paleolimnol., 35, 83-97, 2006.

Caballero, M., Rodriguez, A., Vilaclara, G., Ortega, B., Roy, P., and Lozano García, S.: Hydrochemistry, ostracods and diatoms in a deep, tropical, crater lake in Western Mexico., J. Limnol., 72, 512-523, 2013.

Castro, S. C. D.: Variabilidad de los ciclones tropicales que afectan a México, Interciencia, 35, 306-310, 2010.

Cuna, E., Zawisza, E., Caballero, M., Ruiz-Fernández, A. C., Lozano-García, M. S., and Alcocer, J.: Environmental impacts of Little ice Age cooling in central Mexico recorded in the sediments of a tropical alpine lake, J. Paleolimnol., 51, 1-14, 2014.

Curtis, J. H., Hodell, D. A., and Brenner, M.: Climate variability on the Yucatan Peninsula (Mexico) during the past 3500 years, and implications for Maya cultural evolution, Quaternary Res., 46, 37-47, 1996.

Delorme, L. D.: Freshwater Ostracodes, in: Methods in quaternary ecology, edited by: Warner, B. G., Geological Association of Canada, 93-100, 1990.

Eugster, P. H. and Hardie, L. A.: Saline lakes, in: Lakes: chemistry, geology, physics, edited by: Lerman, A., Springer, New York, 237-293, 1978.

Evans, M., and Heller, F.: Environmental magnetism: principles and applications of enviromagnetics, Academic press, 2003.

Ferrari, L., Petrone, C. M., Francalanci, L., Tagami, T., Eguchi, M., Conticelli, S., Manetti, P., and Venegas-Salgado, S.: Geology of the San Pedro - Ceboruco Graben, western Trans-Mexican Volcanic Belt, Revista Mexicana de Ciencias Geológicas, 20, 165$181,2003$.

Forester, R.: Nonmarine calcareous microfossil sample preparation and data acquisition procedures, United States Geological Survey Technical Proceed HP-78 RI, 1-9, 1988.

Gálvez-Rosales, M.: Unidades habitacionales y ceremoniales en el paraje Los Ciruelos, Paso de San Juan, Nayarit, in: Entre ríos y montañas sagradas: arqueología en El Cajón, Nayarit, edited by: Barrera-Rodríguez, R., Consejo Nacional para la Cultura y las Artes, Instituto Nacional de Antropología e Historia, Comisión Federal de Electricidad, México, 29-43, 2006.

García-Oliva, F., Camou, A., and Maass, J. M.: El clima de la región central de la costa del Pacífico mexicano, Historia natural de Chamela, 3-10, 2002.

Gierlowski-Kordesch, E. H.: Lacustrine carbonates, Develop. Sedimentol., 61, 1-101, 2010.

Gill, R. B.: The great Maya droughts: water, life, and death, UNM Press, 2001.

Haug, G. H., Hughen, K. A., Sigman, D. M., Peterson, L. C., and Röhl, U.: Intertropical Convergence Zone through the Holocene, Science, 293, 1304-1308, 2001.

Haug, G. H., Günther, D., Peterson, L. C., Sigman, D. M., Hughen, K. A., and Aeschlimann, B.: Climate and the collapse of Maya civilization, Science, 299, 1731-1735, 2003.

Hodell, D. A., Brenner, M., Curtis, J. H., and Guilderson, T.: Solar forcing of drought frequency in the Maya lowlands, Science, 292, 1367-1370, 2001.

Hodell, D. A., Brenner, M., and Curtis, J. H.: Terminal Classic drought in the northern Maya lowlands inferred from multiple sediment cores in Lake Chichancanab (Mexico), Quaternary Sci. Rev., 24, 1413-1427, 2005a.
Hodell, D. A., Brenner, M., Curtis, J. H., Medina-González, R., Ildefonso Chan Can, E., Albornaz-Pat, A., and Guilderson, T. P.: Climate change on the Yucatán Peninsula during the Little Ice Age, Quaternary Res., 63, 109-121, 2005b.

Hodgson, D., Vyverman, W., and Tyler, P.: Diatoms of meromictic lakes adjacent to the Gordon River, and of the Gordon River Estuary in south-west Tasmania., Bibliotheca Diatomologica, 174 pp., 1997.

Liebmann, B., Bladé, I., Bond, N. A., Gochis, D., Allured, D., and Bates, G. T.: Characteristics of North American summertime rainfall with emphasis on the monsoon, J. Climate, 21, 12771294, 2008.

Lozano-García, M. S., Caballero, M., Ortega, B., Rodríguez, A., and Sosa, S.: Tracing the effects of the Little Ice Age in the tropical lowlands of Eastern Mesoamerica, Proc. Natl. Acad. Sci. USA, 104, 16200-16203, 2007.

Lozano-García, S., Sosa-Najera, S., Sugiura, Y., and Caballero, M.: $23000 \mathrm{yr}$ of vegetation history of the Upper Lerma, a tropical high-altitude basin in Central Mexico, Quaternary Res., 64, 7082, 2005.

Lozano-García, S., Caballero, M., Ortega, B., Sosa, S., Rodríguez, A., and Schaaf, P.: Late Holocene palaeoecology of Lago Verde: evidence of human impact and climate change in the northern limit of the neotropics during the late formative and classic periods, Veg. Hist. Archaeobot., 19, 177-190, 2010.

Maasch, K., Mayewski, P., Rohling, E., Stager, J., Karlen, W., Meeker, L., and Meyerson, E.: A 2000-year context for modern climate change, Geografiska Annaler: Series A, Phys. Geogr., 87, 7-15, 2005.

Magaña, V. O., Vázquez, J. L., Pérez, J. L., and Pérez, J. B.: Impact of El Niño on precipitation in Mexico, Geofísica Internacional, 42, 313-330, 2003.

Mann, M. E., Bradley, R. S., and Hughes, M. K.: Northern hemisphere temperatures during the past millennium: inferences, uncertainties, and limitations., Geophys. Res. Lett., 26, 759-762, 1999.

Manzanilla, L.: Metrópolis prehispánicas e impacto ambiental: el caso de Teotihuacan a través del tiempo., in: Escenarios de cambioclimático: registros del Cuaternario en América Latina I, edited by: Caballero, M., and Ortega, B., Universidad Nacional Autónoma de México, México, 287-320, 2011.

Metcalfe, S. E., O'Hara, S. L., Caballero, M., and Davies, S. J.: Records of Late Pleistocene-Holocene climatic change in Mexico - a review, Quaternary Sci. Rev., 19, 699-721, 2000.

Metcalfe, S. E., Jones, M. D., Davies, S. J., Noren, A., and MacKenzie, A.: Climate variability over the last two millennia in the North American Monsoon region, recorded in laminated lake sediments from Laguna de Juanacatlán, Mexico, The Holocene, 28, 1195-1206, 2010.

Mingram, J., Negendank, J. F., Brauer, A., Berger, D., Hendrich, A., Köhler, M., and Usinger, H.: Long cores from small lakes - recovering up to $100 \mathrm{~m}$-long lake sediment sequences with a high-precision rod-operated piston corer (Usinger-corer), J. Paleolimnol., 37, 517-528, 2007.

Nyberg, J., Malmgren, B. A., Kuijpers, A., and Winter, A.: A centennial-scale variability of tropical North Atlantic surface hydrography during the late Holocene, Palaeogeogr. Palaeoclimatol. Palaeoecol., 183, 25-41, 2002. 
PAGES-2k-Consortium: Continental-scale temperature variability during the past two millennia, Nature Geosci., 6, 339-346, 2013.

Peterson, C. G. and Stevenson, R. J.: Resistance and resilience of lotic algal communities: importance of disturbance timing and current, Ecology, 73, 1445-1461, 1992.

Pollard, H. P.: Michoacán en el mundo mesoamericano prehispánico: Erongarícuaro, Michoacán y los estados teotihuacano y tarasco, El antiguo occidente de México: nuevas perspectivas sobre el pasado prehispánico, Instituto Nacional de Antropología e Historia, México, 283-303, 2005.

Reimer, P. J., Baillie, M. G. L., Bard, E., Bayliss, A., Beck, J. W., Bertrand, C. J., Blackwell, P. G., Buck, C. E., Burr, G. S., Cutler, K. B., Damon, P. E., Edwards, R. L., Fairbanks, R. G., Friedrich, M., Guiderson, T. P., Hogg, A. G., Hughen, K. A., Kromer, B., McCormac, G., Manning, S., Ramsey, C. B., Reimer, R. W., Remmele, S., Southon, J. R., Stuiver, M., Talamo, S., Taylor, F. W., van der Plicht, J., and Weyhenmeyer, C. E.: IntCa104 terrestrial radiocarbon age calibration, 0-26 cal kyr BP, Radiocarbon, 46, 1029-1058, 2004.

Serrano, D., Filonov, A., and Tereshchenko, I.: Dynamic response to valley breeze circulation in Santa Maria del Oro, a volcanic lake in Mexico, Geophys. Res. Lett., 29, 1649, doi:10.1029/2001g1014142, 2002.
Sieron, K., and Siebe, C.: Revised stratigraphy and eruption rates of Ceboruco stratovolcano and surrounding monogenetic vents (Nayarit, Mexico) from historical documents and new radiocarbon dates, J. Volcanol. Geotherm. Res., 176, 241-264, 2008.

Sosa-Nájera, S., Lozano-García, S., Roy, P. D., and Caballero, M.: Registro de sequías históricas en el occidente de México con base en el análisis elemental de sedimentos lacustres: El caso del lago de Santa María del Oro, Boletín de la Sociedad Geológica Mexicana, 62, 437-451, 2010.

Stuiver, M., Reimer, P. J., and Reimer R. W.: CALIB 5.0 radiocarbon calibration program and documentation (on line), 2005.

Van Dam, H., Mertens, A., and Sinkeldam, J.: A coded checklist and ecological indicator values of freshwater diatoms from the Netherlands, Netherland J. Aquat. Ecol., 28, 117-133, 1994.

Vázquez-Castro, G., Ortega-Guerrero, B., Rodríguez, A., Caballero, M., and Lozano-García, S.: Mineralogía magnética como indicador de sequía en los sedimentos lacustres de los últimos ca. 2,600 años de Santa María del Oro, occidente de México, Revista Mexicana de Ciencias Geológicas, 25, 21-38, 2008.

Vázquez, G. and Caballero, M.: The structure and species composition of the diatom communities in tropical volcanic lakes of eastern Mexico, Diatom Res., 28, 77-91, 2013.

Wolfe, A. P. and Härtling, J. W.: The late Quaternary development of three ancient tarns on southwestern Cumberland Peninsula, Baffin Island, Artic Canada: paleolimnological evidence from diatoms and sediment chemistry, J. Paleolimnol., 15, 1-18, 1996. 